\title{
A New Positive Economic Theory of Negligence
}

\author{
Mark F. Grady $\dagger$
}

Within the last generation, economic analysis has produced a wealth of insights into common law principles and especially into the common law of tort. ${ }^{1}$ Two distinct traditions have emerged within the economic approach to tort law. The normative tradition attempts to evaluate the economic desirability of liability rules with a view toward reforming them. ${ }^{2}$ In contrast, the positive tradition uses economic concepts to explain common law liability rules with a view toward gaining a better understanding of the rules themselves and of their social consequences. ${ }^{3}$ The hypothesis

$\dagger$ Associate Professor of Law, University of Iowa. I wish to acknowledge the encouragement and assistance of Wesley J. Liebeler, James E. Krier, and George L. Priest in writing this Article. I am also grateful to the participants of the several workshops at which I presented it: the Chicago Law and Economics Workshop, particularly Richard Posner, Richard Epstein, and William Landes; the Yale Law and Economics Workshop, particularly George Priest, Guido Calabresi, Alvin Klevorick, and Henry Hansmann; the Iowa Economics Workshop, particularly Donald McGloskey and John Kennan. Thanks are also due to those others who provided helpful comments on earlier drafts, particularly Harold Demsetz, Ronald Allen, Michael Green, Dorsey Ellis, Steven Burton, Gary Schwartz, and Steven Shavell. I received financial assistance for this work from the Yale Civil Liability Program, the Iowa faculty fellowship program, and the U.C.L.A. graduate economics fellowship program.

1. The history of the law and economics movement is discussed in Landes \& Posner, The Positive Economic Theory of Tort Law, 15 GA. L. REV. 851, 852-56 (1981); G. Priest, The Rise of Law and Economics (Oct. 28, 1982) (unpublished manuscript on file with Civil Liability Program, Yale Law School).

2. The leading normative theorist and the co-founder of the economic approach to tort is Guido Calabresi, whose fully developed theory is laid out in G. CALABRESI, THE COSTS OF ACCIDENTS: A LEGAL AND ECONOMIC ANALYSIS (1970). The earliest statement of his theory is in Calabresi, Some Thoughts on Risk Distribution and the Law of Torts, 70 YALE L.J. 499 (1961). Other important articles by Calabresi on the normative economic theory of tort are Calabresi, Concerning Cause and the Law of Torts: An Essay for Harry Kalven, Jr., 43 U. CHI. L. REV. 69 (1975) [hereinafter cited as Calabresi, Concerning Cause and the Law of Torts]; Calabresi, Fault, Accidents and the Wonderful World of Blum and Kalven, 75 Yale L.J. 216 (1975); Calabresi, Does the Fault System Optimally Control Primary Accident Costs?, 33 LAW \& CONTEMP. PROBS. 429 (1968); Calabresi, Transaction Costs, Resource Allocation and Liability Rules - A Comment, 11 J.L. \& EcoN. 67 (1968); Calabresi, The Decision for Accidents: An Approach to Nonfault Allocation of Costs, 78 HARV. L. REV. 713 (1965); Calabresi \& Hirschoff, Toward a Test for Strict Liability in Torts, 81 YALE L.J. 1055 (1972); Calabresi \& Melamed, Property Rules, Liability Rules, and Inalienability: One View of the Cathedral, 85 HARV. L. REV. 1089 (1972).

The other co-founder of the economic approach to tort is Ronald Coase, whose leading work in this area is Coase, The Problem of Social Cost, 3 J.L. \& ECON. 1 (1960). Some parts of Coase's analysis are normative, see id. at 36-38, and other parts are positive, see id. at 19-28. Coase's theory has been reconsidered and extended in Cooter, The Cost of Coase, 11 J. LEGAL STUD. 1 (1982); Demsetz, When Does the Rule of Liability Matter?, 1 J. LEGAL STUD. 13 (1972). The most recent important contribution to the normative economic theory of tort is Rizzo \& Arnold, Causal Apportionment in the Law of Torts: An Economic Theory, 80 CoLUM. L. REV. 1399 (1980).

3. The leading work in the positive economic theory of tort is Posner, $A$ Theory of Negligence, 1 
that the positive economic theory of tort seeks to confirm or refute is that tort rules are designed to minimize social cost-the sum of precaution costs expended in attempting to prevent accidents and injury costs resulting when such accidents occur. ${ }^{4}$

Positive theory must have means to ascertain which liability rules minimize social cost and whether the actual liability rules that courts employ do so. Thus, each positive tort theory contains two parts. First, there is a formal part that posits particular rules and ascertains their social consequences using the tools of economic theory. Second, there is an empirical part that assesses whether the rules posited in the formal model correspond to decision rules that courts actually use. Any particular positive theory of tort can thus be challenged on two levels: that its formal liability rules would not minimize social cost or that its formal liability rules do not correspond to the ones that courts use.

This Article seeks to provide an alternative to the conventional theory of negligence law, set forth by John Prather Brown, ${ }^{5}$ William Landes, and Richard Posner. ${ }^{6}$ First, it discusses the formal negligence rules speci-

J. LEGal STUD. 29 (1972). Other important contributions by Richard Posner and William Landes are Landes \& Posner, Causation in Tort Law: An Economic Approach, 12 J. LEGAL STUD. 109 (1983) [hereinafter cited as Landes \& Posner, Causation]; Landes \& Posner, supra note 1; Landes \& Posner, An Economic Theory of Intentional Torts, 1 INT'L L. \& ECON. REV. 127 (1981); Landes \& Posner, Joint and Multiple Tortfeasors: An Economic Analysis, 9 J. LEGAL STUD. 517 (1980) [hereinafter cited as Landes \& Posner, Joint and Multiple Tortfeasors]; Landes \& Posner, Salvors, Finders, Good Samaritans, and Other Rescuers: An Economic Analysis of Law and Altruism, $7 \mathrm{~J}$. LEGAL STUD. 83 (1978). Additional significant contributions by Posner alone are R. POSNER, ECONOMIC ANAlYsis OF LaW 119-61 (2d ed. 1977); Posner, Privacy, Secrecy, and Reputation, 28 Buffalo L. REV. 1 (1979); Posner, The Right of Privacy, 12 GA. L. REV. 393 (1978); Posner, Strict Liability: A Comment, 2 J. LEGAL STUD. 205 (1973). Important contributions to the positive economic theory of tort by scholars other than Landes and Posner include Brown, Toward an Economic Theory of Liability, 2 J. LEGAL STUD. 323 (1973); Diamond, Accident Law and Resource Allocation, 5 BELL J. ECON. \& MGMT. SCI. 366 (1974); Diamond \& Mirlees, On the Assignment of Liability: The Uniform Case, 6 BELI. J. ECON. \& MGMT. SCI. 487 (1975); Green, On the Optimal Structure of Liability Laws, 7 BELL J. ECON. \& MGMT. SCI. 553 (1976); Shavell, An Analysis of Causation and the Scope of Liability in the Law of Torts, 9 J. LEGAL STUD. 463 (1980) [hereinafter cited as Shavell, Causation and the Scope of Liability]; Shavell, Strict Liability Versus Negligence, 9 J. LEGAL STUD. 1 (1980); Wittman, Optimal Pricing of Sequential Inputs: Last Clear Chance, Mitigation of Damages, and Related Doctrines in the Law, $10 \mathrm{~J}$. LEGAL STUD. 65 (1981).

4. This condition is somewhat different from the Kaldor-Hicks welfare test, which states that a transfer from $A$ to $B$ is efficient when $B$ 's gain in utility is more than sufficient to compensate $A$ for his loss. In its weakest form, the test states that such a transfer is efficient even if $B$ does not actually compensate $A$. For a discussion of the test, see W. BAUMOL, ECONOMIC THEORY AND OPERATIONS ANALYSIS 528-31 (4th ed. 1977). For a provocative discussion of different standards of efficiency, see Coleman, Efficiency, Exchange, and Auction: Philosophic Aspects of the Economic Approach to Law, 68 CALIF. L. REV. 221 (1980). On the related controversy surrounding the hypothesis that tort law is attempting to maximize wealth, see Dworkin, Is Wealth a Value?, 9 J. LEGAL STUD. 191 (1980); Kronman, Wealth Maximization as a Normative Principle, 9 J. LEGAL STUD. 227 (1980).

5. Brown, supra note 3. This theory replaced some of Richard Posner's earlier theory, which he developed in Posner, A Theory of Negligence, supra note 3. Posner and Landes have now adopted the Brown theory of breach of duty in preference to Posner's original theory on this subject. See Landes \& Posner, supra note 1 , at 865 n.41.

6. Landes and Posner have significantly extended the Brown theory in Landes \& Posner, Causa- 
fied by this theory. Next, it argues that these rules do not lead to minimum social cost under conditions of uncertainty. As an alternative, it proposes a new formal rule that appears more surely to lead to minimum social cost under uncertainty. Finally, it shows that this new negligence rule is more consistent with the actual decision rules used by courts than the formal rules posited by the conventional theory.

\section{The Conventional Positive Theory of Negligence}

A negligence rule performs two tasks. ${ }^{7}$ First, it determines when an injurer-usually the defendant ${ }^{8}$ - has not taken enough precaution. This task is performed by the "breach of duty" element of negligence. Second, a negligence rule decides when an injurer's insufficient precaution makes him liable for the victim's loss. This is the "causation" element of negligence. Only when the injurer's breach of duty was the legal cause of the victim's loss will the injurer be liable for it under the rule of negligence. There are two corresponding parts to the positive economic theory of negligence: one about breach of duty and another about legal causation.

\section{A. Defining Breach of Duty}

The conventional theory of negligence defines breach of duty by comparing an individual's actual level of precaution with the level that minimizes social costs. ${ }^{\ominus} \mathrm{I}$ will call the social-cost-minimizing precaution level $\mathrm{P}^{*}$ and the conventional method of defining breach of duty the $\mathrm{P}^{*}$-comparison approach. Under the conventional theory, whenever an injurer has imposed loss on a victim and the injurer's actual precaution was less than the $\mathrm{P}^{*}$ level, the injurer has committed a breach of duty.

Figure 1 is a geometrical depiction of the negligence problem. It shows, from an injurer's perspective, the marginal costs and benefits (measured along the $y$-axis) associated with different levels of precaution (measured along the $\mathrm{x}$-axis).

The curve labeled $R$ denotes the marginal reduction in expected harm at different levels of precaution. ${ }^{10}$ The height of the R-curve at a particu-

tion, supra note 3; Landes \& Posner, supra note 1; Landes \& Posner, Joint and Multiple Tortfeasors, supra note 3.

7. See Shavell, Causation and the Scope of Liability, supra note 3, at 463-64.

8. In some proximate cause situations, there will be more than one injurer, one of whom may not be a defendant. See Pittsburg Reduction Co. v. Horton, 87 Ark. 576, 113 S.W. 647 (1908). Also where contributory or comparative negligence is involved the plaintiff is simultaneously the victim and one of his own injurers. See Landes \& Posner, Joint and Multiple Tortfeasors, supra note 3, at 518; Wittman, supra note 3 . This Article does not analyze problems of victim fault or of proximate cause.

9. Brown, supra note 3, at 328; Landes \& Posner, supra note 1, at 873-74; Landes \& Posner, Joint and Multiple Tortfeasors, supra note 3, at 521-22.

10. In Figure $1, R$ decreases as $P$ increases. Thus, additional units of precaution decrease expected harm by decreasing amounts. This assumption is consistent with the traditional economic as- 
lar precaution level is the reduction in expected harm that would result from a one-unit increase in precaution. The area under the R-curve between one precaution level and another is the reduction in expected accident costs caused by the increase in precaution over the interval. For example, if precaution is increased from $P_{1}$ to $P^{*}$, expected harm decreases by an amount equal to the sum of areas III and IV. The area defined by points $\mathrm{O}, \mathrm{A}$, and $\mathrm{P}_{\max }$ represents the total harm that would be expected if no precaution were taken. ${ }^{11}$

\section{Figure 1}



sumption of diminishing marginal returns.

11. For the total area under the R-curve to correspond to the total expected harm that would exist if the injurer took zero precaution one must assume that total expected harm at $\mathbf{P}_{\max }$ is zero. This assumption will aid the exposition, but will not limit the generality of the analysis that follows.

An R-curve is defined only with respect to some amount of information. This level of information is assumed to be given (or exogenous) when the R-curve is drawn. The amount of information that courts use in estimating expected harm is "reasonable foresight." The Figure 1 R-curve is thus assumed to be drawn based on reasonable foresight. The theory of what amount of information constitutes reasonable foresight is beyond the scope of this Article. The area superscribed by the R-curve can be called the "reasonably foreseeable risk"; it is the amount and type of expected harm that reasonable foresight would predict.

Although Shavell does not ise the R-curve construct, he has a theory about how courts determine the relevant expected harm. See Shavell, Causation and the Scope of Liability, supra note 3, at 48589. 


\section{Positive Theory of Negligence}

The curve labeled $\mathrm{C}$ represents the marginal cost of precaution. In Figure 1 , this curve is flat, reflecting a constant marginal cost for all levels of precaution. ${ }^{12}$ The area under the G-curve between one precaution level and another is the increase in the total cost of precaution that results from the increase in precaution over the interval. Thus, if precaution is increased from $P_{1}$ to $P^{*}$, the cost of precaution increases by an amount equal to area IV.

The optimal level of precaution, $\mathrm{P}^{*}$, which minimizes the sum of expected harm and precaution cost, ${ }^{13}$ is the precaution level at which the Rand the C-curves intersect. When actual precaution is less than $\mathrm{P}^{*}$, society would benefit from additional precaution; conversely, when actual is greater than $\mathrm{P}^{*}$, society would benefit from less precaution. Precaution level $P_{1}$ is not optimal because an increase in precaution to $P^{*}$ would decrease expected harm by an amount equal to the sum of areas III and IV, but would increase precaution cost only by an amount equal to area IV. Thus, the net social saving from this increase in precaution is equal to area III, which is the amount by which social cost at $P_{1}$ exceeds social cost at $\mathrm{P}^{*}$. Because social cost is lower at $\mathrm{P}^{*}$, social cost cannot be at a minimum when the injurer is operating at $P_{\mathbf{1}}$. Similarly, precaution level $\mathbf{P}_{\mathbf{2}}$ is not optimal; using analogous reasoning one can easily determine that decreasing precaution to $\mathrm{P}^{*}$ would result in a net social saving equal to the area V.

\section{B. Determining Legal Causation}

Under the $\mathrm{P}^{*}$-comparison approach, an individual who has taken due care-has selected $\mathrm{P}^{*}$-is not liable for any harm that he has imposed on another. Victims will still be harmed by the injurer's activity. Their expected losses will equal the areas of VI and VII, but the injurer will not be liable for these "unavoidable accidents." liability - not under a rule of negligence-would an injurer who has taken $\mathrm{P}^{*}$ be liable for such losses. ${ }^{15}$

12. The analysis in this Article is not dependent upon the assumption of constant marginal costs. To avoid corner solutions, however, the $\mathrm{G}$ - and $\mathrm{R}$-curves must intersect, and the $\mathrm{C}$-curve cannot fall at a faster rate than the $\mathrm{R}$-curve.

13. The model here is simplified by assuming that the level of activity is independent of the level of precautionary behavior, that is, that reductions in the level of production are not an available precaution strategy, and hence not potential costs of precaution. For an example of a model in which reducing the level of activity is one possible precautionary strategy, see Shavell, Causation and the Scope of Liability, supra note 3 , at 465 (taking into account "benefits parties derive from engaging in their activities").

14. See Brown v. Kendall, 60 Mass. (6 Cush.) 292, 297 (1850).

15. In traditional strict liability, there is liability for the entire amount under the R-curve. See, e.g., Smith v. Lockheed Propulsion Co., 247 Cal. App. 2d 774, 56 Cal. Rptr. 128 (1967); Siegler v. Kuhlman, 81 Wash. 2d 448, 502 P.2d 1181, cert. denied, 411 U.S. 983 (1973). So, if strict liability attaches to concussion harm from rocket testing, there would be liability for all concussion harm under 
A question about legal causation arises only when an injurer has committed a breach of duty by taking less precaution than $\mathrm{P}^{*} .{ }^{16}$ Courts using the $\mathrm{P}^{*}$-comparison approach to breach of duty could resolve this legal causation problem in either of two possible ways. One way would be to hold the negligent individual ${ }^{17}$ strictly liable for all harm that results. Under this rule, which I will call the full liability rule, an injurer operating at $\mathbf{P}_{\mathbf{1}}$ is liable for the entire amount of expected harm that remains at $P_{1}$ - the areas III, IV, VI, and VII. ${ }^{18}$ Alternatively, a court might impose liability on an injurer only if the accident would have been prevented had the individual exercised due care. ${ }^{19}$ Under this latter rule, which I will call the $\mathrm{P}^{*}$-cutoff rule, an injurer operating at $\mathrm{P}_{1}$ would be liable only for an amount equal to the areas III and IV.

The two rules embody very different notions of legal causation. The causal concept implicit in the $\mathrm{P}^{*}$-cutoff rule is but-for causation. Under this rule, courts conduct an evaluation ${ }^{20}$ of whether an accident that has occurred could have been prevented if the injurer had exercised due care. ${ }^{21}$

the R-curve regardless of how much precaution was taken. The rocket tester, however, would not be strictly liable for non-concussion harm (if strict liability does not attach to it).

16. In legal analysis the problem of causation is not always posterior to the problem of breach of duty. Courts will sometimes assume a breach of duty, for the sake of analysis, in order to dispose of a case on easy causation grounds. See, e.g., McDowall v. Great Western Ry., [1903] 2 K.B. 331, 338 (G.A.) (Vaughan William, L.J.); infra pp. 827-28 (discussing Nussbaùm v. Lacopo, 27 N.Y.2d 311, 265 N.E.2d 762, 317 N.Y.S.2d 347 (1970)); infra note 67 (discussing McDowall). For present purposes, it is convenient to analyze the two negligence issues, breach of duty and cause in fact, as if breach of duty were always the prior question.

17. For purposes of this Article, a negligent individual is one who commits a breach of duty.

18. This full liability negligence rule is the one used in Shavell, Causation and the Scope of Liability, supra note 3, at 489 ("once one recognizes that under the negligence rule there is an important element of strict liability (for a variety of reasons a party attempting to exercise due care may be found negligent), all the results concerning the scope of liability under strict liability become relevant under the negligence rule"). Landes and Posner also used the full liability model of negligence in Landes \& Posner, Joint and Multiple Tortfeasors, supra note 3, at 521-22; Landes \& Posner, supra note 1 , at 874,882 .

19. This is the approach that Landes and Posner seem to take in their most recent article. See Landes \& Posner, Causation, supra note 3, at 115-18.

20. Unlike breach of duty, which is largely an ex ante standard, cause in fact is an ex post determination.

21. See New York Cent. R.R. v. Grimstad, 264 F. 334 (2d Cir. 1920). This is the most rigorous formulation of cause in fact. When it is not certain whether this test is met, a problem of evidence and presumptions arises that is beyond the scope of this Article. It can be said, however, that the greater the breach of duty, the more probable it is that the untaken precaution would have prevented the harm. Thus, less independent evidence of cause in fact will be required when the untaken precaution is of a character that "greatly multiplies the chances of accident." Reynolds v. Texas \& P. Ry., 37 La. Ann. 694 (1885). In other words, less independent evidence of cause in fact is needed when the defendant was at $P_{1}$ than when he was at a precaution level infinitesimally less than $P^{*}$ (and the breach of duty is shown in both cases with the failure to take $\mathrm{P}^{*}$ ). Because the plaintiff can offer several different untaken precautions as alternative theories of the breach of duty, there can be several cause in fact issues in a given case, that is, whether untaken precaution $x$ would have prevented the harm, whether untaken precaution $y$ would have prevented the harm, and so forth. See, e.g., Allied Chem. Corp. v. Hess Tankship Co., 661 F.2d 1044, 1052-54 (5th Cir. 1981); Stacy v. Knickerbocker Ice Co., 84 Wis. 614, 616-17, 54 N.W. 1091, $1091-92$ (1893).

The courts have relaxed the requirement of but-for causation in the special situation of concurrent 
In contrast, under the full liability rule the relevant concept is that of a "causal link": Courts attempt to ascertain, on an actuarial basis, whether the harm that the victim suffered resulted from the injurer's activity and was of the kind that more precaution by the injurer would have reduced or prevented. ${ }^{22}$ Thus, the full liability rule has a less restrictive notion of causation than does the $\mathrm{P}^{*}$-cutoff rule.

Despite these differences, both rules will induce injurers to exercise the level of precaution that minimizes social cost under conditions of perfect certainty. Under either rule, injurers will have an incentive to operate at $\mathrm{P}^{*}$.

Consider the full liability rule first. An individual will never exercise precaution greater than $\mathrm{P}^{*}$. Operating at $\mathrm{P}^{*}$, he will be found to have exercised due care and thus be shielded from liability. Precaution beyond $\mathrm{P}^{*}$ will increase the injurer's precaution costs, but will not reduce his expected liability (which, by definition, will already be zero) ${ }^{23}$ Similarly, an injurer will not choose to operate below $\mathrm{P}^{*}$. Suppose for example that he chose $\mathrm{P}_{\mathbf{1}}$ as his level of precaution. He would then face an expected liability equal to the sum of areas III, IV, VI, and VII. By expending an amount equal to area IV in additional precaution, that is, by moving to $\mathrm{P}^{*}$, he can reduce his expected liability to zero, thus saving an amount equal to the sum of areas III, VI, and VII. This argument is a general one, as it does not depend on the distance between $\mathrm{P}^{*}$ and $\mathrm{P}_{\mathbf{1}}{ }^{24}$

sufficient causation where two causal chains for which two different people are responsible each would have been sufficient to cause the plaintiff's harm. See, e.g., Corey v. Havener, 182 Mass. 250, 65 N.E. 69 (1902); Kingston v. Chicago \& N.W. Ry., 191 Wis. 610, 211 N.W. 913 (1927). This is a relatively rare but interesting situation. Shavell has given an account of the economic policy underlying the special rule for cases of this type. Shavell, Causation and the Scope of Liability, supra note 3, at 494-95. The special situation of concurrent sufficient causation is beyond the scope of this Article. The peculiar problems of successive causation of the type involved in Maddux v. Donaldson, 362 Mich. 425, 108 N.W.2d 33 (1961), are also beyond the scope of this Article.

For an excellent discussion of the general problem of cause in fact, see Weinrib, A Step Forward in Factual Causation, 38 MOD. L. REV. 518 (1975).

22. Calabresi originally developed the concept of causal link in Calabresi, Concerning Cause and the Law of Torts, supra note 2, at 71 ("There is a causal link between an act or activity and an injury when we conclude on the basis of the available evidence that the recurrence of that act or activity will increase the chances that the injury will also occur.").

23. Following the conventional theory, see Landes \& Posner, supra note 1 , at $867-68$, I assume that individuals are risk-neutral. I also assume that litigation and settlement costs are so low that all plaintiffs with meritorious negligence cases are compensated for the full amount of their damages, so that injurers expect to be liable for all legally recoverable harm. Proponents of the conventional theory have made the same assumption. See id. at 882 .

24. There is, however, an important qualification regarding this exposition. Each individual's Rcurve is a function of the precaution taken by other individuals. To facilitate the exposition of the central argument of this Article, this interdependency is ignored. As a formal matter, the interdependency is not significant for the problems analyzed here when: (1) the injurer knows that other individuals will exercise the levels of precaution that would be optimal given optimal precaution by the injurer himself; or (2) these other individuals either make their precaution choices before the injurer does or do not have the opportunity of noticing the increased risk created by the injurer's suboptimal precaution. In terms of the example used below, see infra pp. 807-08, the people living beneath the 
Now, consider the $\mathrm{P}^{*}$-cutoff rule. Once again, an individual will never operate beyond $\mathrm{P}^{*}$ because he will be shielded from liability by picking $\mathrm{P}^{*}$. Neither will an individual pick $\mathrm{P}_{1}$, because at that level he would face an expected liability equal to the sum of areas III and IV. (An injurer subject to the $\mathrm{P}^{*}$-cutoff rule who is operating at $\mathrm{P}_{\mathbf{1}}$ will not face liability for areas VI and VII because the but-for cause requirement will shield him from liability for accidents that would have occurred even if he had exercised due care.) By moving from $P_{1}$ to $P^{*}$ he can decrease his expected liability by an amount equal to the sum of areas III and IV. These savings can be accomplished by expending an amount equal to area IV in additional precaution. Thus, the exercise of due care will lead to a private saving equal to area III.

The major claim of the conventional positive theory of negligence law is that the $\mathrm{P}^{*}$-comparison approach will lead to the minimization of social cost. The preceding discussion shows that under conditions of perfect certainty, this result is independent of whether the scope of liability is limited by a restrictive but-for causation requirement or a broad causal link requirement.

\section{A Critique of the Conventional View}

The two rules for defining the scope of liability have different consequences for a negligent individual, but both create an incentive for individuals to exercise due care under conditions of perfect certainty. This result, while correct, is somewhat counterintuitive. In a model in which behavior is shaped by expected costs, one would imagine that the choice between liability rules having different economic consequences should affect the conduct of a potential injurer. The absence of these effects suggests an underlying rigidity in the specification of the model. For this reason, it is important to focus on whether the behavioral results that flow from the model depend on unduly restrictive assumptions.

My critique of the conventional theory stems from the examination of the effects of the assumption that injurers can always identify with perfect certainty the precaution level that courts will determine to be $\mathrm{P}^{*}{ }^{25}$ Proba-

dam are assumed to be taking precaution consistent with the dam owner being at $\mathrm{P}^{*}$, and they are assumed to be unable to notice the increased risk that results when the dam owner takes less precaution than $P^{*}$.

25. Brown assumes that both courts and injurers make no errors in identifying $P^{*}$. As to courts, he writes, "For our purposes the only function of the legal system is the impeccable administration of whatever liability rule is in force. In order to concentrate on what is our major concern, the parties' behavior, we ignore . . the mistakes that a court can make ...." Brown, supra note 3, at 327 . That injurers also do not make errors in estimating $\mathrm{P}^{*}$ is implicit in Brown's assumption that they know their own R-curves and G-curves perfectly. He writes, "Both parties [injurer and victim] are assumed to know $A$ [the magnitude of harm that will resuit if precaution is not taken], $W_{X}$ [the injurer's C-curve], $W_{y}$ [the victim's G-curve], and $P(X, Y)$ [the R-curve that depends on the levels of 
bly the best way for an injurer to assess whether he is at $\mathrm{P}^{*}$ would be for him to consider whether there are any further precautions-beyond those currently planned or taken-that would reduce expected harm by a greater amount than the cost that they would impose. This is also the most plausible way by which a court could determine whether an injurer was taking less precaution than $\mathrm{P}^{*}$. If the injurer was operating at some level below $\mathrm{P}^{*}$, such as $\mathrm{P}_{1}$, either the court or injurer could determine this to be the case by finding some further precaution beyond $P_{1}$ that would have cost less than the amount by which it would have reduced expected harm. In contrast, if the injurer is at $\mathrm{P}^{*}$, no further precaution can be found that will yield a net benefit.

The incentives to make this analysis accurately are very different before an accident than after an accident. For example, most dams will never

injurer and victim precaution]." Id. at 335. Shavell also expressly assumes that courts make no errors in locating $\mathrm{P}^{*}$ : "[S]ince we assume the courts have perfect information about accidents, they make no 'mistakes.' They correctly calculate the level of due care; they 'observe' with complete accuracy the level of care actually exercised by injurers, and so on." Shavell, Causation and the Scope of Liability, supra note 3, at 485 . Implicit in Shavell's analysis of causation is also the idea that injurers do not make mistakes estimating $P^{*}$, because they are assumed to know with certainty whether they are taking due care. He writes, "When deciding whether to exercise due care (clearly, he will not wish to exercise more than due care), the injurer will have to consider the consequences of exercising less than due care, of acting in a negligent way." Id. at 486 . But see id. at 489 ("for a variety of reasons a party attempting to exercise due care may be found negligent"). The general premise of Shavell's causal analysis is that the injurer can know the due care level with certainty and can also correctly predict the expected liability from exercising less than due care, though both of these assumptions are more implicit than explicit.

Landes and Posner's assumptions on whether courts and injurers can make mistakes are no longer clear. In Landes \& Posner, Joint and Multiple Tortfeasors, supra note 3, at 521, they make no express assumption about whether either courts or injurers make mistakes in locating $P^{*}$, though it scems implicit in their analysis as it develops that neither courts nor injurers make errors very frequently, if they do at all. In Landes \& Posner, supra note 1 , at 879 , they expressly assume that both injurers and courts can make mistakes, but they do not explicitly analyze the consequences of either assumption. In their most recent article, Causation in Tort Law: An Economic Approach, apparently anticipating the reasoning of this Article on the tendency of the full liability rule to induce overprecaution, see infra pp. 811-12, they write that their own analysis

may appear to overlook an easier route, not involving administrative costs, to the conclusion

that there should be no liability in this class of cases [where there is no cause in fact]: if the

defendant is liable for accidents he could not prevent, he will use excessive care. This reasoning is incorrect, however - at least under certain conditions concerning the nature and implementation of the liability standard. If the standard is negligence, if negligence has no stochastic element, if the negligence standard is applied on an individual rather than average basis, and if the standard is applied correctly in every case, then liability of however broad a scope will have only one effect, and that is to induce the defendant to take due care and thereby avoid liability. In these circumstances, to impose liability for accidents that could not have been prevented (or whose probability could not have been lowered) by due care is no different from imposing punitive damages for negligent behavior. However severe, the sanction will not induce any inefficient behavior; it will induce the taking of care, which will avoid the sanction completely.

Landes \& Posner, Causation, supra note 3, at 117. They then add that these assumptions are "excessively restrictive," id., but they do not say what the proper assumptions are. It is therefore difficult to assess whether they are assuming that injurers and courts make errors. It would appear, however, that they are assuming that at least courts which, they say, apply the standard "correctly in every case," do not make errors. 
produce any overflow harm, whether the walls are 110 feet high $\left(\mathrm{P}_{1}\right)$ or 120 feet high $\left(\mathrm{P}^{*}\right)$. Before the accident, the value of information to the potential injurer that $\mathrm{P}^{*}$ is 120 feet-not 110 feet-will approach the area III, under the $\mathrm{P}^{*}$-cutoff rule, or the areas III, VI, and VII under the full liability rule. If the expected liability from operating at 110 feet is $\$ 100,000$, the value of this information to the injurer before the accident is some fraction of this amount: It is slightly less than $\$ 100,000$ minus the cost of the additional precaution that would insulate the injurer from liability. Now, let us suppose, the unlikely occurs and the dam does overflow, and damages totalling $\$ 1,000,000$ result. The value of the information to the victim that a further precaution would have been costbeneficial will now approach $\$ 1,000,000$ and the value of the contrary information will have an equal value to the injurer. Therefore, it would not be surprising that at trial the information that the court will receive about the costs and benefits of 120 -foot walls versus 110 -foot walls will be far more perfect than the information that the dam owner would have found it economical to collect before the accident. It would thus seem reasonable to assume that the courts after a trial will be able to assess whether actual precaution was less than $\mathrm{P}^{*}$ far more accurately than will an injurer before an accident. ${ }^{26}$ For the sake of analysis, let us assume that courts do not make mistakes in estimating $\mathrm{P}^{*}$, but that injurers do. Although this is a strong assumption, it is somewhat realistic in that the prior reasoning would indicate that injurer estimates of $\mathrm{P}^{*}$ before an accident would be significantly less accurate than court estimates after an accident. Also, this assumption that courts do not make mistakes is the same as that made by the conventional theory. ${ }^{27}$

Although injurers are estimating $\mathrm{P}^{*}$ based on imperfect information, there is no reason to suppose that their information is biased in favor of either overprecaution or underprecaution. Therefore, I assume that when they estimate $\mathrm{P}^{*}$ they are just as likely to guess high as low. If we call injurer estimates of $\mathbf{P}^{*}$ their $\hat{P}^{\prime} s$, it follows from the last assumption that the $\hat{\mathrm{P}}$-distribution is a symmetric distribution whose mean is $\mathrm{P}^{*}$.

26. It is true, of course, that if an accident causing a harm of $\$ 100$ occurred the plaintiff and defendant would have little incentive to introduce much evidence at trial. But for the vast majority of activities, the probability that an accident-any accident-will occur is quite small over the time period in which the set of precautions in question is a sunk cost. Thus, it is reasonable to assume that once an accident takes place, the harm that is caused will be greater than the expected harm, given that expected harm is equal to the sum of the products of actual harms and the probabilities that accidents causing such harms will occur.

There is, however, a group of activities for which this proposition will not hold. An injurer who is involved in very large numbers of accidents (for example, an auto manufacturer) will often estimate expected harm before an accident with practically the same accuracy as a court after an accident. Many injurers of this type, however, seem to be regulated by principles of products liability rather than by principles of negligence.

27. See supra note 25 . 
Finally, I assume that injurers make small errors in estimating $\mathrm{P}^{*}$. Thus, an injurer is not uncertain that zero precaution is less than $\mathrm{P}^{*}$, nor is he uncertain that $\mathrm{P}_{\max }$ is greater than $\mathrm{P}^{*}$. He is only uncertain whether his estimate is greater or less than $P^{*}$ when his estimate is between $P_{1}$ and $\mathrm{P}_{2}$ (a small band around $\mathrm{P}^{*}$ ). ${ }^{2 \mathrm{~B}}$

Once an injurer has estimated $\mathrm{P}^{*}$-has selected his $\hat{\mathrm{P}}$-the important social question becomes whether he will actually take the level of precaution that he has estimated. The injurer is not bound to take his $\hat{P}$ under either of the two rules. Whether the injurer actually will take the level of precaution that he has estimated to be $\mathrm{P}^{*}$ depends on the penalties he faces when his actual choice is not equal to $P^{*}$. Every liability rule creates two kinds of penalties: a penalty for taking more precaution than $\mathrm{P}^{*}$ and one for taking less precaution than $\mathrm{P}^{*}$. In deciding whether actually to operate at $\hat{\mathrm{P}}$ when he is not certain whether $\hat{\mathrm{P}}$ is greater or less than $\mathrm{P}^{*}$, the injurer must consider and compare the magnitudes of these penalties. At an extreme, if the penalty for taking less precaution than $\mathrm{P}^{*}$ is one million dollars and the penalty for taking greater precaution than $\mathrm{P}^{*}$ is one cent, an injurer would never actually operate at $\hat{\mathrm{P}}$, his estimate of $\mathrm{P}^{*}$, if he is at all uncertain where a court would locate $\mathrm{P}^{*}$. Instead, the injurer would add a substantial "insurance factor" to his $\hat{\mathrm{P}}$ estimate to minimize the probability that the level of precaution that he ultimately takes is lower than $\mathrm{P}^{*}$.

Although the point has never been stressed by the conventional positive economic theory, which concludes that both liability rules will produce the optimal result, ${ }^{29}$ the full liability and $\mathrm{P}^{*}$-cutoff rules assign very different penalties for injurer errors, and they induce very different injurer behavior under conditions of uncertainty. In fact, neither rule produces the optimal behavior under these conditions. The full liability rule will frequently induce injurers to take more precaution than $\mathrm{P}^{*}$, and the $\mathrm{P}^{*}$-cutoff rule will frequently induce injurers to take less precaution than $P^{*}$.

\section{A. The Full Liability Rule}

Suppose that an injurer has estimated $\hat{\mathrm{P}}$ at a value that is infinitesimally less than $\mathrm{P}^{*}$. If the injurer takes his $\hat{\mathrm{P}}$ estimate as his actual precaution level, the court would find that he has committed a breach of duty. His expected liability under the full liability rule would be infinitesimally greater than the sum of areas VI and VII. If instead an injurer takes a

28. These limits are important to the analysis here because the R-curve may not be a straight line. If the $R$-curve is convex throughout its range from zero to $P_{\operatorname{mxx}}$, however, it will approximate a straight line within a small band around $\mathrm{P}^{*}$. The narrower the band of error, of course, the more the R-curve will approximate a straight line within it.

29. See supra pp. 805-07. 
precaution level that is infinitesimally greater than $\mathrm{P}^{*}$, the loss that he would suffer is of a different magnitude and nature. It would be merely the infinitesimally small cost of precaution that the injurer could have saved without being subjected to additional liability for accidents. This "sword of Damocles" effect suggests that given a choice between one unit of overprecaution and one unit of underprecaution, the injurer will choose the overprecaution. ${ }^{30}$

Figure 2

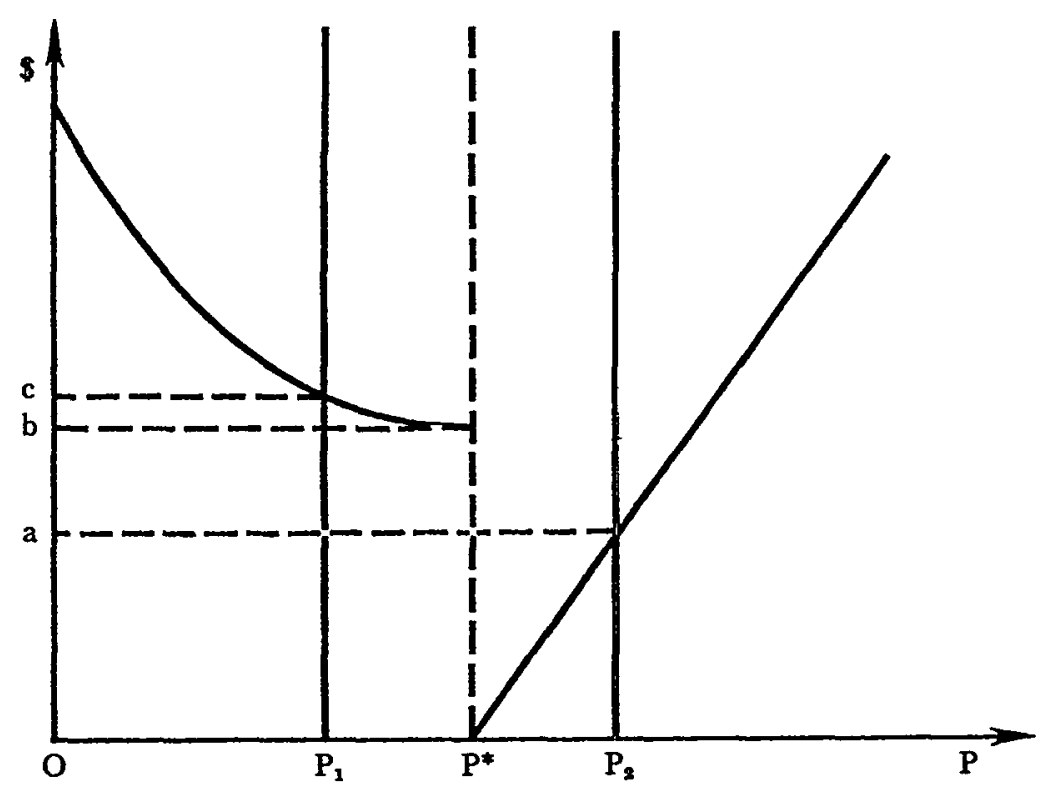

To establish this point more rigorously, consider Figure 2, which depicts the penalties that an injurer subject to the full liability rule faces when he overinvests and underinvests in precaution. In this Figure, the height of the penalty curve above the $x$-axis indicates the magnitude of the penalty that the injurer will incur at given levels of precaution. By definition, at $\mathrm{P}^{*}$ the value of the penalty function is zero because at this level the injurer minimizes the sum of his precaution costs and expected liability. If the injurer takes infinitesimally less precaution than $\mathrm{P}^{*}$, the penalty that the injurer incurs is the value $b$ indicated on the y-axis of Figure 2. This value equals the sum of the areas VI and VII on Figure 1. By moving from a precaution level infinitesimally less than $\mathrm{P}^{*}$ to $\mathrm{P}^{*}$ itself, which would cost the injurer only an infinitesimal amount in additional precaution, the injurer saves the areas VI and VII in expected liability; thus, the

30. In fact, the actual result is even more striking. See infra pp. 811-12. 
penalty function is discontinuous.

The value $b$ on Figure 2 is a fixed component of the penalty, which attaches whenever an injurer operates at a precaution level less than $\mathrm{P}^{*}$. In addition, the penalty for underinvesting also has a variable component. At $P_{1}$, an injurer faces an expected liability equal to the sum of the areas III, IV, VI, and VII. Relative to operating at $\mathrm{P}^{*}$, however, he saves an amount of precaution cost equal to the area IV by being at $P_{1}$. Thus, the penalty for being at $P_{1}$ is the sum of areas III, VI, and VII. The area III is the variable component of the penalty function; this component shrinks to zero as the injurer moves from $P_{1}$ to $P^{*}$. In Figure 2,c is equal to the penalty at $\mathrm{P}_{1}$; the difference between $b$ and $c$ equals the area III on Figure $1 .{ }^{31}$

The value of the full liability penalty function for precaution levels greater than $\mathrm{P}^{*}$ is simply the amount under the G-curve between $\mathrm{P}^{*}$ and the precaution level in question. The penalty that the injurer incurs from being at $\mathrm{P}_{2}$ is the areas V and VI on Figure 1 , because the areas $\mathrm{V}$ and VI are needless expense. Because courts correctly locate $\mathrm{P}^{*}$, operating at $\mathrm{P}^{*}$ itself avoids liability just as well as operating at $\mathrm{P}_{2}$. On Figure 2, the value of the areas $\mathrm{V}$ and $\mathrm{VI}$ is denominated $a$. Within the range that is relevant to this analysis, $a$ is always less than $c ; \mathrm{P}_{\mathbf{2}}$ imposes a lesser penalty on the injurer than does $P_{1}$. Thus, within this relevant range, the full liability rule always imposes a larger penalty for underprecaution than for overprecaution; in fact, the penalty for operating at $P_{2}$ is smaller than the penalty for operating at a level only infinitesimally less than $P^{*}{ }^{32}$

An uncertain injurer is therefore not indifferent between the two kinds of error. To attempt to avoid the "sword of Damocles" effect of underprecaution, an injurer subject to the full liability rule will add an insurance factor to his $\hat{P}$ estimate. Thus, the distribution of actual precaution choices (which I will call the $\overline{\mathrm{P}}$-distribution) will be dislocated to the right of the $\hat{\mathbf{P}}$ distribution by an amount equal to the insurance factor. ${ }^{33}$ The most

31. The full liability penalty function is decreasing in slope (is convex) at levels of precaution less than $\mathrm{P}^{*}$. This is so because area III has a triangular shape. On the other hand, the full liability penalty function has a constant slope at levels of precaution greater than $\mathrm{P}^{*}$ because the areas $\mathrm{V}$ and VI, when combined, have a rectangular shape.

32. The value $b$ on Figure 2 is greater than the value $a$ because the areas VI and VII on Figure 1 - the fixed component of the penalty from underprecaution-are greater than the areas V and VI, which together constitute the penalty from the greatest possible error of overprecaution $\left(\mathrm{P}_{2}\right)$. See supra p. 809 . Within the relevant range, see $i d$., these conditions make the penalty from any injurer error of underprecaution, no matter how small, greater than the penalty from the maximum possible overprecaution. Given any significant doubt, the injurer strongly prefers $P_{2}$ to some much smaller level of underprecaution.

33. It is assumed that all injurers add the same insurance factor. If not, the full liability $\overline{\mathrm{P}}$ distribution still will be dislocated to the right of the $\hat{\mathbf{P}}$-distribution and will also have a somewhat different variance (or shape) than the $\hat{\mathbf{P}}$-distribution. Even with different insurance factors for different injurers, the full liability $\overline{\mathrm{P}}$-distribution will still be less desirable than a $\overline{\mathrm{P}}$-distribution exactly coincident to the $\hat{\mathrm{P}}$-distribution, so long as each injurer's insurance factor is positive. The assumption 
likely actual precaution choice (the mean of the full liability $\overline{\mathrm{P}}$-distribution) will not be $\mathrm{P}^{*}$ itself but will be some precaution level greater than P*.

\section{B. The $P^{*}$-Cutoff Rule}

The results under the $\mathrm{P}^{*}$-cutoff rule are less striking but equally important. If an injurer chooses an actual precaution level infinitesimally lower than $\mathrm{P}^{*}$, the injurer will face liability only over an infinitesimally small range. On the other hand, if an injurer chooses an actual precaution level infinitesimally greater than $\mathrm{P}^{*}$, the injurer will not face any liability, and his loss will be an infinitesimally small amount of overprecaution. Thus, the P*-cutoff rule produces no "sword of Damocles" effect. Nonetheless, the analysis of the relative penalties for underprecaution and overprecaution is important because it reveals that under the $\mathrm{P}^{*}$-cutoff rule an uncertain injurer will choose one unit of underprecaution over one unit of overprecaution - the exact opposite of the behavior induced by the full liability rule. ${ }^{34}$

In Figure 1, suppose that the injurer has taken precaution level $P_{1}$. At that level, he faces liability for areas III and IV; in order to avoid this liability he would have to incur an amount equal to area IV in additional precaution costs. Hence, the penalty for being at $P_{1}$ instead of at $P^{*}$ is area III. On the other hand, if the injurer took an equal amount of overprecaution-precaution level $\mathrm{P}_{2}$-the penalty for not being at $\mathrm{P}^{*}$ would be the sum of areas V and VI, which is the amount spent in useless additional precaution. Because areas III and V are equal, an injurer given the choice between operating at $\mathrm{P}_{1}$ or $\mathrm{P}_{2}$ will pick $\mathrm{P}_{1}$, and thereby save an amount equal to area VI. More generally, one can say that an uncertain injurer faced with the $\mathrm{P}^{*}$-cutoff rule will prefer a given amount of underprecaution over an equal amount of overprecaution.

Figure 3, which depicts the penalty function for the $\mathrm{P}^{*}$-cutoff rule, illustrates two noteworthy results. First, there is no discontinuity in the value of the penalty function at $\mathrm{P}^{*}$, as there was for the full liability rule. Second, consistent with the prior reasoning, the magnitude of the penalty

that each injurer's insurance factor is the same seems to follow both from the assumption that all injurers are risk neutral, which is a standard assumption in the conventional theory, see supra note 23, and from the absence of an a priori reason to assume that people engaging in the same activity (building the same-sized dam) would entertain very different judgments about the probability that their estimates of $\mathrm{P}^{*}$ would be wrong. Indeed, the estimates of $\mathrm{P}^{*}$ made by different injurers will be subject to similar costs and rewards.

34. The result under the $\mathrm{P}^{*}$-cutoff rule is less striking than that under the full liability rule, where any overprecaution in the relevant ranges is more desirable than any underprecaution. Sec supra note 32 .

The $\mathrm{P}^{*}$-cutoff penalty function decreases in slope at levels below $\mathrm{P}^{*}$ and has constant slope at levels above $\mathrm{P}^{*}$. See supra note 31 . 
for underprecaution (the height of the penalty function at any precaution level) is always less than that for an equal amount of overprecaution. In Figure 3 , the value $d$-the penalty from being at $\mathrm{P}_{1}$-is equal to the area III on Figure 1. The value a, once again, is equal to the areas V and VI in Figure 1.

Figure 3

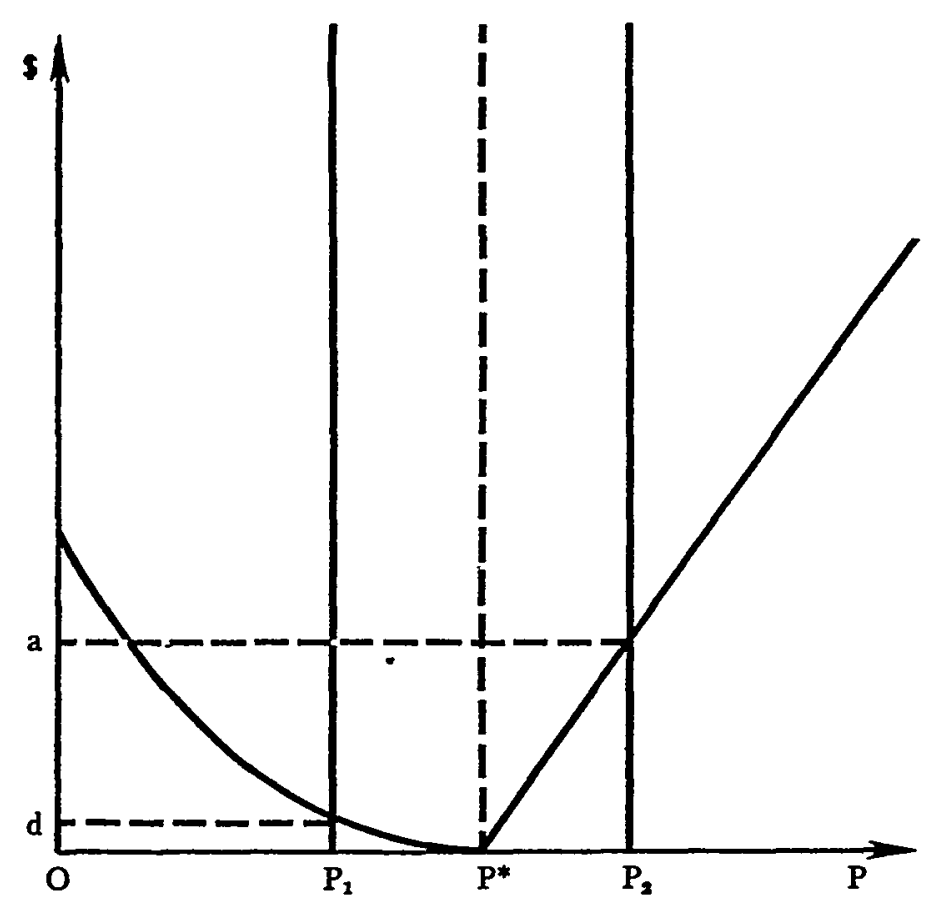

Under the $\mathrm{P}^{*}$-cutoff rule, an individual estimating $\mathrm{P}^{*}$ under conditions of uncertainty will have the same $\hat{\mathrm{P}}$ distribution as he would under the full liability rule. This time, though, when he is making his decision about what precaution level to take, he does not add an insurance factor to his $\hat{\mathbf{P}}$ estimate; instead, being aware that underprecaution imposes a lower penalty than overprecaution, he subtracts a "low ball" factor. In doing so, the injurer assumes that he is better off by underinvesting more than half of the time and overinvesting less than half of the time; therefore, he takes a level of precaution less than his estimate of $\mathrm{P}^{*}$. The distribution of actual precaution choices produced by these unequal penalties, $\overline{\mathrm{P}}$, will be dislocated to the left of the $\hat{\mathrm{P}}$-distribution. The mean of actual precaution choices will be less than $\mathrm{P}^{*}$, even though the mean of injurer estimates is exactly $\mathrm{P}^{*}$. 


\section{The New Theory}

The preceding critique of the conventional positive theory of negligence demonstrates that the major claim of that theory-that the $\mathrm{P}^{*}$-comparison test promotes minimum social cost-does not hold under the very realistic assumption that injurers will not always be able correctly to identify P*. It is important to emphasize that in making the critique, I did not assume that injurers are incapable of ascertaining $P^{*}$. I merely assumed that in attempting to find $\mathrm{P}^{*}$ injurers will sometimes make mistakes. I conceded, however, that these mistakes would be random and symmetrically distributed around $\mathrm{P}^{*}$. These specifications are not radically different from those of the conventional model ${ }^{35}$ a fact that makes the critique all the more striking. First, random errors by injurers do not produce random variations in the level of precaution, but systematic variations. Second, the two rules that have so far coexisted in the conventional theory with little attention having been paid to their difference ${ }^{36}$ lead to dramatically different results. As an alternative to both rules, I propose a new formal theory, which I will call the cost-benefit approach. This theory retains the concept of legal causation of the $\mathrm{P}^{*}$-cutoff rule, but defines breach of duty in a manner altogether different from the $\mathrm{P}^{*}$-comparison approach. Under conditions of uncertainty, the new theory leads to results that are more socially desirable than those produced by its conventional counterparts.

\section{A. The Cost-Benefit Approach}

Under the $\mathrm{P}^{*}$-comparison approach, courts determine breach of duty by comparing an injurer's actual level of precaution to $\mathrm{P}^{*}$. If actual precau-

35. See supra note 25.

36. See supra pp. 809-13. In their most recent article, Landes and Posner seem to argue that their formulation of the $\mathrm{P}^{*}$-cutoff rule was always implicit in "the economist's" theory of negligence, even in its full liability form. They analyze Weeks v. McNulty, 101 Tenn. 495, 48 S.W. 809 (1898), in which the court found that, although the defendant committed a breach of duty by failing to install fire escapes, he was not liable because fire escapes would not have prevented the decedent's death. Landes \& Posner, Causation, supra note 3, at 116-17. This case seems scarcely explainable if courts are adopting the full liability rule. Nonetheless, Landes \& Posner argue that "the economist" would have been right all along to think of $M c N u l t y$ as a case in which there was no negligence. As they reason:

Now there may seem an element of paradox in asserting that McNulty was not really negligent, when the premise of the court's decision was that he had been negligent per se but should be excused for want of a causal relationship between negligence and injury. But this just shows that the courts do in two steps what the economist, via the refined version of the Hand formula, does in one. The court first asks whether there is negligence in a rather crude sense, a failure to do something which in the general run of cases would be socially cost justified and then, under the rubric of causation, inquires whether the taking of additional care would have been socially cost justified in the particular circumstances of the case, given other factors that may have made additional care fruitless.

Id. at 116. This account of why the differences between the $\mathrm{P}^{*}$-cutoff rule and the full liability rule were not noticed seems to be an over-simplification. 
tion is less than $\mathrm{P}^{*}$ there is a breach of duty; if actual precaution is at least equal to $\mathrm{P}^{*}$, there is no breach of duty. Suppose, instead, that courts listen to allegations of untaken precautions-for example, the failure to build a 120-foot wall on a dam, the failure to place a fence around a swimming pool, or the failure to station a lifeguard on a beachfront-and find an injurer negligent whenever the costs of at least one specific untaken precaution are less than the reduction in expected harm that would have resulted from that precaution. They would then impose liability if the specific act of negligence used to prove the breach of duty was the cause in fact of the harm the victims suffered-that is, when but for the failure to take the particular precaution constituting the defendant's breach of duty the plaintiff's harm would not have occurred.

Although one might at first imagine that this cost-benefit approach is really the same as the $\mathrm{P}^{*}$-comparison approach, there are some significant differences between them. The most important difference between the two approaches is that under the cost-benefit approach the maximum level of untaken precaution that can be used to show breach of duty is not fixed, but depends on the injurer's actual level of precaution. For example, if the injurer is taking precaution level $P_{1}$, the plaintiff can point to any precaution level smaller than $P_{2}$ and successfully argue that the injurer's failure to have taken that precaution level was a breach of duty. This result follows easily from Figure 1 . Because $P_{1}$ and $P_{2}$ are equidistant from $P^{*}$, area III is equal to area $V$ and area IV is equal to the sum of areas $V$ and VI. It follows that areas IV, V and VI (the additional costs of taking $\mathbf{P}_{\mathbf{2}}$ ) are exactly equal to areas IV, III and VI (the additional benefits from taking $\mathrm{P}_{2}$ ). For any precaution level smaller than $\mathrm{P}_{2}$, the additional benefits outweigh the additional costs. On the other hand, if the injurer's actual precaution is not $P_{1}$, but instead a level infinitesimally smaller than $\mathrm{P}^{*}$, the maximum untaken precaution that the plaintiff could use to prove breach of duty would be an amount infinitesimally greater than $\mathrm{P}^{*} .{ }^{37}$

Thus, as the injurer takes less precaution, he creates more opportunities

37. The cost-benefit approach is a theory about specific negligence cases. Res ipsa loquitur cases, which are beyond the scope of the conventional theory, are also beyond the scope of this Article. There is no clear line of demarcation between res ipsa and specific negligence cases, because the difference between them depends on the degree to which the plaintiff proves negligence using particular untaken precautions. The clearest case of specific negligence is where the plaintiff offers a highly defined untaken precaution as proof of the breach of duty (the failure to build the dam wall 120 feet high). The clearest case of res ipsa loquitur (or general negligence as it was once called) is where the plaintiff offers no particular untaken precaution to prove the breach of duty (the dam was within the exclusive control of the defendant, dams do not ordinarily overflow in the absence of negligence, and so forth). The middle case is where the plaintiff alleges negligence in very general terms (the failure to operate and maintain the dam using due care). Depending on whether the proof uncovers a particular untaken precaution that might constitute a breach of duty, this middle kind of case is properly seen either as a res ipsa case or as a specific negligence case, or as one that went to the jury on alternative theories. 
for the victim to show a breach of duty. In this sense, the cost-benefit approach permits alternative proofs of breach of duty, and the levels of untaken precaution available for the victim's proof increase as the injurer's actual precaution decreases. In contrast, under the $\mathrm{P}^{*}$-comparison standard the maximum untaken precaution that the victim can use to prove breach of duty is $P^{*}$, regardless of whether the injurer is at $P_{1}$ or a precaution level infinitesimally less than $\mathrm{P}^{*}$, and negligence can never be premised on the failure to take a precaution level greater than $\mathrm{P}^{*}$.

This new cost-benefit approach shares an important feature with the conventional approach. If an injurer is operating at least at level $\mathrm{P}^{*}$, he cannot be found negligent under either approach. From the geometry of Figure 1, it is clear that the cost of any precaution beyond $\mathrm{P}^{*}$ will always be higher than the corresponding reduction in expected harm.

Why would the victim ever want to prove the breach of duty with an untaken precaution beyond $\mathrm{P}^{*}$ ? If the injurer had been operating at a level slightly over $P_{1}$, why not prove that the breach of duty was the failure to take $\mathrm{P}^{*}$ ? It should be easier to prove that the failure to take $\mathrm{P}^{*}$ was a breach of duty than it would be to show that the injurer was negligent because he failed to operate at $P_{2}$. The benefits of taking $P^{*}$ instead of a little more precaution than $P_{1}$ exceed the additional costs by a significant amount (area III). In contrast, the benefits of taking $P_{2}$ are only infinitesimally greater than the increase in costs. Why go to the limit?

By merely proving that the injurer was negligent by failing to operate at $\mathrm{P}^{*}$, the plaintiff might fail to prove legal causation. Suppose on Figure 1 that $P_{1}$ is a 110 -foot wall for a dam, $P^{*}$ is a 120 -foot wall, and $P_{2}$ is a 130 -foot wall. Suppose also that the plaintiff's property floods and that this flood could have been prevented only by a wall at least 125 feet high. If the victim establishes breach of duty with the dam owner's failure to build a 120-foot wall $\left(\mathrm{P}^{*}\right)$, the victim will fail on the cause in fact issue. The court will say, "It may be true as you say that the defendant was negligent in failing to build the wall up to 120 feet, but you have not shown that a 120 -foot wall would have prevented the harm that actually occurred, and therefore you have failed to prove that the defendant's negligence was the cause in fact of that harm." ${ }^{38}$ To avoid losing the case on

38. As the court said in City of Piqua v. Morris, 98 Ohio St. $42,54,120$ N.E. 300,303 (1918), which was a dam overflow case:

An apt illustration which has been suggested is that if a river levee had been maintained at the height of 10 feet and the custodians of the levee had been warned that flood waters might require a levee 16 feet in height, and they neglected to so increase the height of the levee, and an unprecedented flood should ensue, during which it should appear that a levee 26 feet in height would not have held the flood waters, the parties responsible for the levee would not be liable for negligence in failing to maintain a 16-foot levee, when a 26-foot levee would have been unavailing.

In other words, the plaintiff must pick an untaken precaution level sufficiently high so that it would 
the cause in fact issue, the plaintiff must carry a heavier burden on the breach of duty issue. ${ }^{39}$ In particular, the plaintiff must show that the failure to build the wall up to some height higher than 125 feet was a breach of duty. Only this more ambitious proof of the breach of duty issue will satisfy the cause in fact requirement.

The "zone" of liability created by the cost-benefit rule, that is, by joining the cost-benefit approach to breach of duty with the but-for cause in fact requirement, is different than that of the two rules of the conventional theory. Under the cost-benefit rule, an injurer operating at $\mathrm{P}_{1}$ faces expected liability in the areas III, IV, and VI. By contrast, under the $\mathrm{P}^{*}$ cutoff rule, he would face liability only in areas III and IV; under the full liability rule, the areas of expected liability are III, IV, VI, and VII.

\section{B. Evaluating the Cost-Benefit Approach}

Under conditions of certainty, the cost-benefit rule, like the $\mathrm{P}^{*}$-cutoff and full liability rules, leads to the socially optimal level of precaution. An individual would not operate above $\mathrm{P}^{*}$ under the cost-benefit rule, because doing so would not reduce his expected liability, but would result in additional precaution costs. Consider, however, the possibility that he might operate at $\mathrm{P}_{1}$, a level below $\mathrm{P}^{*}$. There, his expected liability would be the sum of areas III, IV, and VI. By expending an amount equal to area IV in additional precaution, the injurer can escape all liability. Thus, he will never intentionally operate at $\mathrm{P}_{1}$. A similar exercise will rule out all other values less than $\mathrm{P}^{*}$.

Now, consider the case of uncertainty. Uncertainty acquires a slightly different meaning under the cost-benefit approach to breach of duty, because this approach assumes that courts are not in the express business of locating $\mathrm{P}^{*}$. Instead, under the cost-benefit approach courts are judging whether at particular actual levels of precaution, the costs of further precautions are greater or less than the benefits. If courts make no mistakes-the same assumption as before-they will locate the least-cost precaution level that will preclude the victim from showing a breach of duty at $\mathrm{P}^{*}$. Therefore, although courts do not expressly locate $\mathrm{P}^{*}$, they behave as if they did. The injurer, as before, can make mistakes. In searching for the least-cost precaution level that will preclude the showing of a breach of duty, $\mathrm{P}^{*}$, he can incorrectly estimate the R-curve or the G-curve. For example, the injurer's pre-accident notions of expected harm may be different from the estimates that he would have made if he had access to

have prevented the particular harm that he sustained. And, he must prove that this same untaken precaution was a breach of duty, given the defendant's actual level of precaution.

39. This tension between the breach of duty and cause-in-fact issues is apparent in Stacy v. Knickerbocker Ice Co., 84 Wis. 614, 54 N.W. 1091 (1893). 
post-trial information. Similarly, he may decide not to build a higher dam, under the impression that the additional cost is greater than the additional benefit, and then find out at trial that new technology available before the dam was built would have made a higher wall cheaper than he had originally thought.

Under uncertainty, the cost-benefit rule has more desirable properties than the conventional rules because it does not create incentives for underprecaution or overprecaution. An injurer operating at $P_{1}$ under the costbenefit approach faces expected liability in areas III, IV, and VI in Figure 1. If, instead, he operated at $\mathrm{P}^{*}$, he would pay an amount equal to area IV in additional precaution, but face no liability. Thus, the penalty from operating at underprecaution $\mathrm{P}_{1}$ is equal to the sum of areas $\mathrm{III}$ and VI. On the other hand, the penalty from operating at $P_{2}$ instead of $P^{*}$ is equal to the areas V and VI, just as it is under the two other rules. Under all three rules, $P^{*}$ will avoid liability just as $P_{2}$ will, so the areas $V$ and VI always represent an expense for needless precaution. What is different about the cost-benefit rule is that it alone makes the penalties from overprecaution and underprecaution equal. When $P_{1}$ and $P_{2}$ are equal but opposite errors, the sum of the areas III and VI (the penalty for underprecaution) exactly equals the sum of the areas V and VI (the penalty for overprecaution), since areas III and $\mathrm{V}$ are congruent triangles.

Another way to see the advantages of the cost-benefit rule is illustrated by Figure 4 . There, because the penalty for underprecaution is exactly the same as the penalty for equal overprecaution, both parts of the cost-benefit rule penalty function have equal (but opposite) slopes. ${ }^{40}$ Also, unlike the full-liability penalty function, the cost-benefit penalty function has no discontinuity at $\mathrm{P}^{*}$. These equal penalties for the two kinds of error have a highly desirable implication for the way that an injurer will approach the question of whether to take the precaution level that he has estimated to be $\mathrm{P}^{*}$. Indeed, once the injurer has made his $\hat{\mathrm{P}}$ estimate, he has no incentive under the cost-benefit rule either to add an insurance factor or to subtract a low ball factor. He is indifferent between opposite but equal errors. Therefore, he will estimate his $\hat{\mathbf{P}}$ and take precisely the amount of his estimate, without biasing his actual precaution choice in either direction.

40. The slopes of the two wings on the cost-benefit rule penalty function are both constant because underprecaution and overprecaution each produce penalties in rectangular (not triangular) areas. Therefore, the penalty for any given increment of error is always the same. 
Figure 4

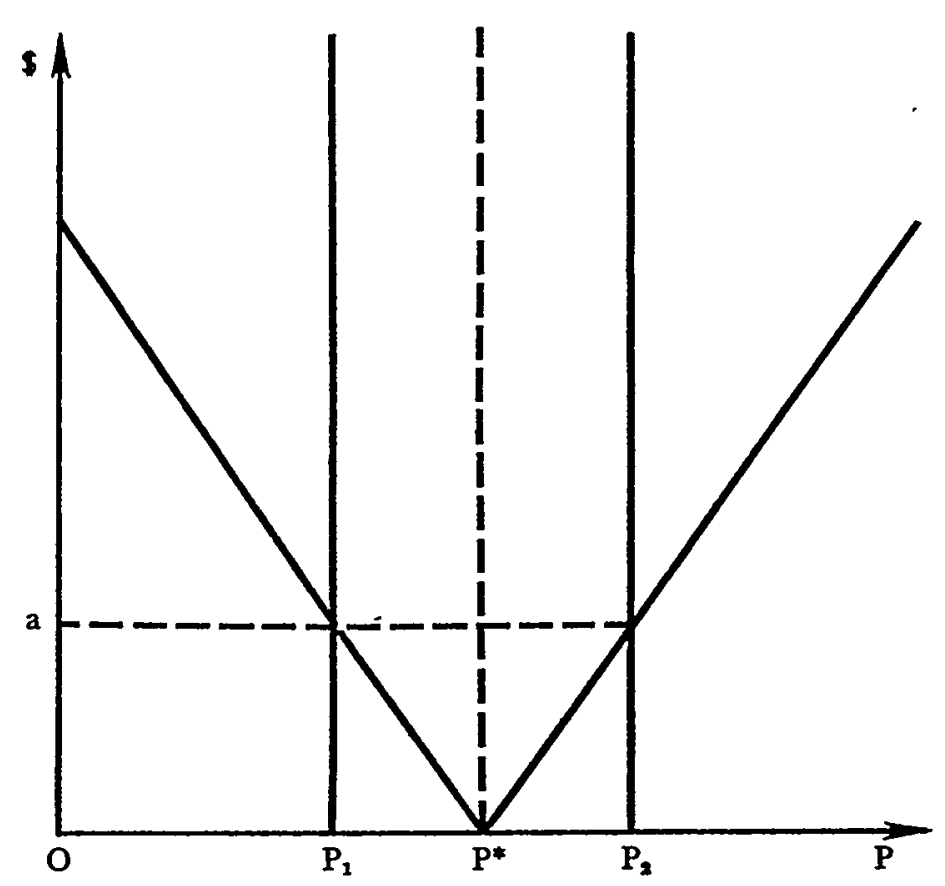

The social consequences of the three alternative negligence rules can be seen on Figure 5. Each rule operates against the same $\hat{\mathbf{P}}$-distribution-the same set of injurer estimates of $\mathbf{P}^{*}$. This $\hat{\mathbf{P}}$-distribution is the middle one, because under the prior assumption injurers are just as likely to estimate $\mathrm{P}^{*}$ high or low, whatever the liability rule. Under the $\mathrm{P}^{*}$-cutoff rule, injurers' actual precaution choices will be dislocated toward lower levels of precaution, because each injurer is subtracting a low ball factor from his estimate of $\mathrm{P}^{*}$, taking an amount of precaution equal to his estimate less the low ball factor. Under the full liability rule, the $\hat{\mathbf{P}}$-distribution also will not be actually realized because injurers are adding an insurance factor to their estimates of $\mathbf{P}^{*}$, taking an amount of precaution that equals their $\hat{\mathrm{P}}$ estimates plus the insurance factor. Hence, each of these two rules produces an actual distribution of precaution, $\overline{\mathrm{P}}$, that is dislocated from the $\hat{\mathrm{P}}$-distribution. In contrast, the distribution of actual precaution choices induced by the cost-benefit rule is exactly the same as the $\hat{\mathbf{P}}$-distribution. The dislocated $\overline{\mathrm{P}}$-distribution produced by the full liability rule might be socially preferable to the alternatives if society lost more from errors of underprecaution than from equal errors of overprecaution. Simi- 
larly, the $\overline{\mathrm{P}}$ distribution of the $\mathrm{P}^{*}$-cutoff rule might be preferable if society preferred underprecaution to overprecaution.

Figure 5

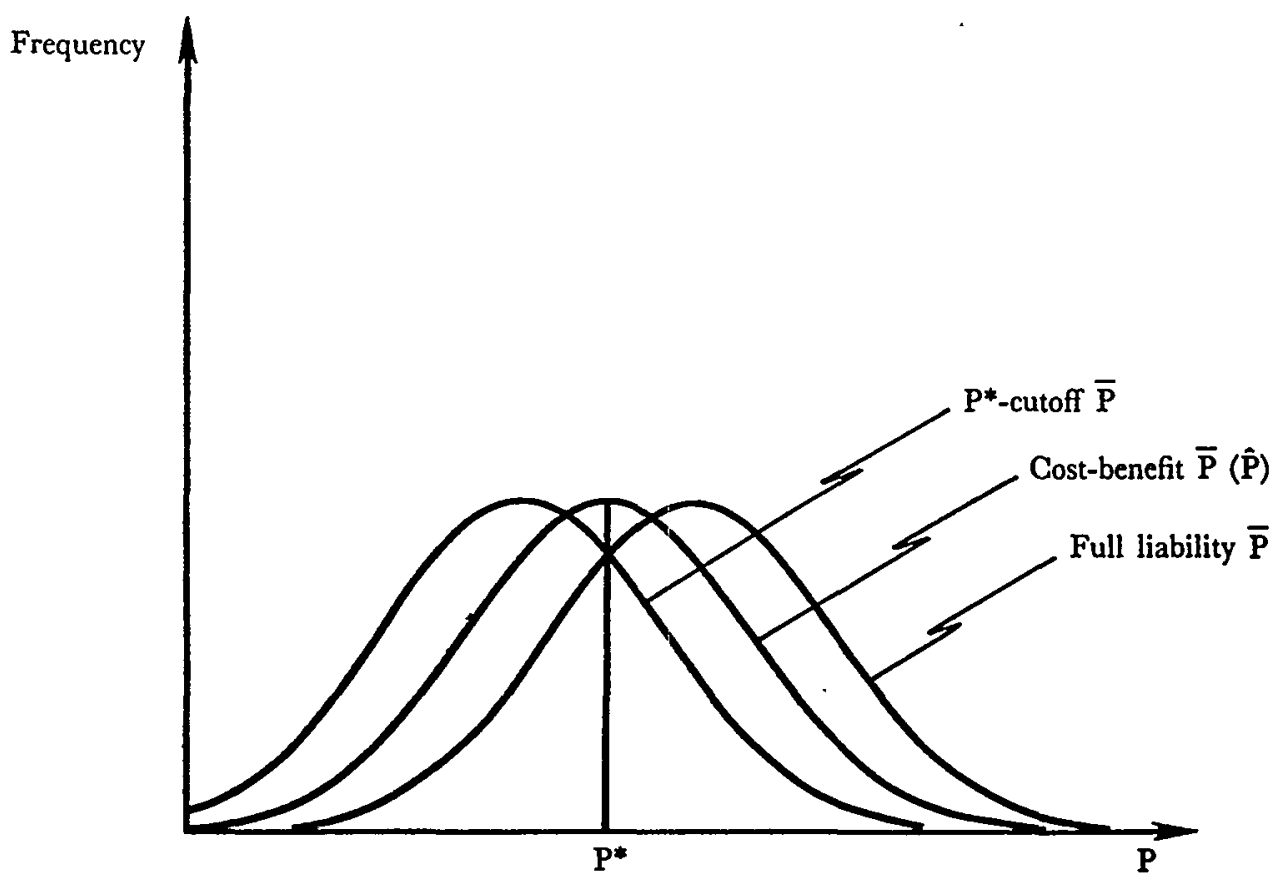

Society, however, loses the same amount from underprecaution as from equal overprecaution. ${ }^{41}$ When the injurer is at $P_{1}$, society foregoes an amount equal to the area III, which represents a possible surplus that society has lost. Similarly, when the injurer is at $P_{2}$, society loses the area $\mathrm{V}$, which represents a deficit that society has incurred. Within a range of error around $\mathrm{P}^{*}$ where the $\mathrm{G}$ - and R-curves can be assumed to be linear, these two areas are equal. ${ }^{42}$ Thus, society is indifferent between errors of underprecaution and equal errors of overprecaution. In addition, because the area of triangles similar to III and V is proportional to the square of the departure from $\mathrm{P}^{*}$, the social loss function is proportional to the sum of the squares of the departures of actual precaution levels from P*. For example, one injurer error that is double another injurer error costs society four times as much. As Figure 5 indicates, for any given $\hat{\mathbf{P}}$-distribution

41. Thus, the private terms of trade between the two types of errors under the cost-benefit approach are the same as the social terms of trade.

42. See supra note 28 . 
of the type previously assumed, society is better off if the $\overline{\mathrm{P}}$-distribution generated by a legal rule is the same as the $\hat{\mathrm{P}}$-distribution than if it shifted away from the $\hat{\mathrm{P}}$-distribution. The $\hat{\mathrm{P}}$-distribution crowds more precaution choices close to $\mathrm{P}^{*}$, the region in which society loses least, than the alternative distributions depicted in Figure 5. Society loses least under the cost-benefit rule because the $\overline{\mathrm{P}}$-distribution generated by that rule is equal to the $\hat{\mathrm{P}}$-distribution. Society does not prefer the full liability $\overline{\mathrm{P}}$ distribution because it is dislocated to the right of the $\hat{\mathrm{P}}$-distribution. By the same token, society does not prefer the $\mathrm{P}^{*}$-cutoff $\overline{\mathrm{P}}$-distribution because it is dislocated to the left of the $\hat{\mathrm{P}}$-distribution. Hence, the costbenefit rule has better formal properties than the rules of the coventional theory.

\section{The New Theory and the Courts}

The preceding discussion shows that the cost-benefit approach can provide a desirable alternative to the formal economic model that underlies the conventional positive theory of negligence. This part shows that the cost-benefit approach is also a more practical one for courts to implement, and that it is more consistent with the way courts actually decide specific negligence cases than either of the two other rules. Thus, from an empirical standpoint, it provides a better basis for positive analysis.

\section{A. The Informational Requirements of the Competing Approaches}

In determining whether a party has acted negligently and should be liable, courts consider certain types of information. The next section shows that the evidence generally before the courts concerns the costs and expected benefits of specific untaken precautions. This information is sufficient to determine the issue of negligence under the cost-benefit rule. As we have seen, under that rule a party is held liable if the cost of an untaken precaution that would have prevented the accident is smaller than the reduction in expected harm that would have resulted from taking that precaution. Under the cost-benefit approach, this condition is necessary and sufficient for a finding of liability. ${ }^{48}$ It can be called the "cost-benefit condition."

Under the $\mathrm{P}^{*}$-cutoff rule the corresponding liability conditions are far more complex. In Figure 1, consider the case of an injurer who has built a 111-foot wall (one foot more than $P_{\mathbf{1}}$ ). The property downstream is flooded, and the property owner can prove that the overflow would have been prevented by constructing a 130 -foot wall $\left(\mathrm{P}_{2}\right)$, but cannot show that

43. This condition will hold provided that proximate cause, duty, and defenses arising from the plaintiff's conduct are not a problem. All of these matters are beyond the scope of this Article. 
the overflow would have been prevented by building a 120 -foot wall $\left(\mathrm{P}^{*}\right)$. From the geometry of Figure 1, it follows that the plaintiff will prevail under the cost-benefit rule. Under the $\mathrm{P}^{*}$-cutoff rule, however, the court would find for defendant. Thus, the cost-benefit condition is not sufficient for a finding of liability under the $\mathrm{P}^{*}$-cutoff rule. If courts actually apply the $P^{*}$-cutoff rule, then after the plaintiff satisfies the cost-benefit condition they must allow the defendant to raise the defense that the accident would have occurred even if the level of precaution had been $\mathrm{P}^{*}$. This defense appears to be missing in negligence law. If it were available, one would expect that it would be a routine feature of negligence litigation, because when the defendant has taken less precaution than $\mathrm{P}^{*}$ there will always be precautions beyond $\mathrm{P}^{*}$ that satisfy the cost-benefit condition.

I know of only one case in which a defendant tried to make an argument similar to the missing defense, and in that case the court rejected the argument. In Haft v. Lone Palm Hotel, ${ }^{44}$ a statute provided that swimming pool managers should either post a sign saying that there was no lifeguard or else provide a lifeguard. Because posting a sign would have precluded liability under the statute, this precaution level has at least a plausible claim for being considered $\mathrm{P}^{*}$, particularly since it is improbable that any precaution as great as providing a lifeguard could be considered to minimize social costs in a motel swimming pool during the off-season time when the accident occurred. ${ }^{45}$ On the cause-in-fact issue, the plaintiff was able to show with much greater force that a lifeguard, rather than a mere warning sign, would have prevented the drowning of her husband and son. The defendant, following a tack very similar to the missing defense, argued that because posting the sign would have precluded the showing of a breach, liability should be tested not by whether a lifeguard would have prevented the deaths-as plaintiff wanted-but by whether a sign would have prevented the deaths. The California Supreme Court rejected the argument. This case, which presented an alternative statutory duty, would seem to provide the most favorable setting for the missing defense to be accepted. In this case, unlike most that would arise in the absence of a statute, it was obvious that if the defendant had taken a precaution level less than the one that the plaintiff had actually used to

44. 3 Cal. 3d 756, 478 P.2d 465, 91 Cal. Rptr. 745 (1970).

45. Of course, $\mathrm{P}^{*}$ will frequently not be a single precaution. In almost all cases, $\mathrm{P}^{*}$ will be a set of precautions that would be optimal with respect to a particular expected harm or "reasonably foreseeable risk." See supra note 10 . With respect to the risk that people may drown in a motel swimming pool during the off-season, the optimal set of precautions would probably include posting a sign that no lifeguard was on duty, having lifesaving equipment nearby, cleaning up any grease that might get onto the pool deck, and so forth. The argument made in the text that it is unlikely that posting a lifeguard at the pool "is $\mathrm{P}^{*}$ " is shorthand for saying that it is unlikely that this precaution is within the set of various precautions (and associated levels of each) that together constitute the $\mathrm{P}^{*}$ set of precautions. 
prove the breach of duty, the plaintiff would have been foreclosed from showing the breach of duty that she did show. When the Haft court rejected the defendant's argument, it rejected the missing defense in a setting most conducive to the defense's success. If this defense existed, the case reports would be filled with its refinements and successes because injurers would frequently wish to rely on it. Instead, the defense that has just been described truly is missing and seems rejected.

Another way that courts could cut off liability at $\mathrm{P}^{*}$ would be to impose some ceiling on the victim's selection of untaken precautions. This ceiling would have to be more restrictive than the cost-benefit condition. One possible ceiling would be custom. Under this restriction, only customary precautions could be alleged to be the breach of duty, even in situations where it appears that the costs of uncustomary precautions were less than their benefits. Yet, courts have long held that in most areas of negligence liability the mere compliance with custom is no defense to the injurer whose breach of duty is predicated on cost-benefit considerations. ${ }^{46}$

46. E.g., Texas \& P. Ry. v. Behymer, 189 U.S. 468, 470 (1903); Wabash Ry. v. McDaniels, 107 U.S. 454, 460-61 (1882); Bahamas Agricultural Indus., Ltd. v. Riley Stoker Corp., 526 F.2d 1174, 1178 (6th Cir. 1975); Princemont Constr. Corp. v. Smith, 433 F.2d 1217, 1220 (D.C. Cir. 1970) (per curiam); The T.J. Hooper, 60 F.2d 737, 740 (2d Cir.), cert. denied, 287 U.S. 662 (1932); Klein v. Mr. Transmission, Inc., 294 Ala. 437, 441-42, 318 So. 2d 676, 679-80 (1975); Roberie v. Sinclair Refining Co., 252 So. 2d 488, 493 (La. Ct. App. 1971); Thompson v. Ohio Fuel Gas Co., 9 Ohio St. 2d 116, 117-19, 224 N.E.2d 131, 134-35 (1967).

The one exception to this principle is medical and possibly other forms of malpractice. In most jurisdictions, the victim injured by a doctor must demonstrate that the untaken precaution used to establish the doctor's breach of duty was customary among doctors. Tant v. Women's Clinic, 382 So. 2d 1120, 1121 (Ala. 1980); Walton v. Jones, 286 N.W.2d 710, 714 (Minn. 1979); see King, In Search of a Standard of Care for the Medical Profession: The "Accepted Practice" Formula, 28 VAND. L. REV. 1213, 1234-35 (1975); McCoid, The Care Required of Medical Practitioners, 12 VAND. L. REV. 549, 605-06 (1959). But see Helling v. Carey, 83 Wash. 2d 514, 519 P.2d 981 (1974) (finding breach of duty of physician based on uncustomary precaution). For discussions of other types of malpractice, see Kenney v. Oak Builders, Inc., 224 So. 2d 161, 168 (La. Ct. App. 1969) (architects); Lambert v. Soltis, $422 \mathrm{~Pa} .304,307-10,221$ A.2d 173, 175-77 (1966) (dentists); Elizondo v. Tavarez, 596 S.W.2d 667, 672-73 (Tex. Civ. App. 1980) (nurses).

The precautions customary among doctors have a good claim for being considered $\mathrm{P}^{*}$, because most doctors would have every expectation that their patients would wish to pay for all precautions whose costs are less than their benefits and, if their patients are risk neutral, for no more. There is a good reason for the law to subject doctors to the $\mathrm{P}^{*}$-cutoff rule, as opposed to the cost-benefit rule. By virtue of his special kind of relationship with his patient, who is the possible victim of his negligence, the doctor faces a penalty function very different from that of most injurers. For the doctor the penalty from being at $P_{1}$ is the sum of the areas III and IV, not just the area III, because if the doctor is ever found at $P_{1}$ he will have the unhappy awareness that his patient would have been willing to pay the area IV for him to have taken $P^{*}$ instead. (In this scenario, the C-curve includes a competitive rate of return for the doctor on the medical procedures that he sells.) On the other hand, if the doctor takes $\mathrm{P}_{2}$, he can recover the area VI in fee even from a perfectly informed patient. Therefore, the doctor's penalty from being at $P_{2}$ is at most the area $V$. For the doctor, then, and possibly for other injurers with similar special relationships to their victims, even the $\mathrm{P}^{*}$-cutoff rule imposes a higher penalty for underprecaution than for equal overprecaution. If courts applied the cost-benefit rule to this peculiar situation, they would further imbalance the penalties for the two types of errors, because the penalty for operating at $P_{1}$ would become the areas III, IV, and VI. It is presumably for this reason that the courts apply a standard more similar to the $P^{*}$-cutoff rule to this special situation. The conventional theory does not make this distinction, but maintains instead that the $\mathrm{P}^{*}$-comparison approach is the 
If courts adopted the full liability rule we would not observe them asking whether the defendant's breach of duty was the but-for cause of the plaintiff's harm. They would be asking instead whether the kind of precaution that the plaintiff failed to take (higher walls) was causally linked to the plaintiff's harm. In other words, if the plaintiff proved that the failure to raise the wall from 110 feet to 112 feet was a breach of duty, the defendant would be liable for the harm done by a 135-foot flood, even though the cost of the additional precaution that would have prevented the accident is greater than the corresponding reduction in expected harm. Thus, the cost-benefit condition cannot be a necessary condition for a finding of liability under the full liability rule. Under this rule, a plaintiff could make an alternative argument and prevail. That argument would contain the following elements: (1) a showing that the reduction in expected harm from any given untaken precaution, no matter how small, exceeds its cost; and (2) a showing that the harm sustained resulted from the defendant's activity. ${ }^{47}$ Under the full liability rule, the plaintiff does not have to show that the untaken precaution used to satisfy the breach of duty requirement also satisfies the cause in fact requirement by being one that would have prevented the particular harm that the plaintiff sustained.

In summary, to justify the $\mathrm{P}^{*}$-cutoff rule, its proponents need to show that courts apply the defense that shields a negligent defendant from liability for untaken precautions beyond $\mathrm{P}^{*}$, even if such untaken precautions satisfy the cost-benefit condition. To justify the full liability rule they need to show that the cost-benefit comparison need not involve the actual untaken precaution that would have prevented the accident. In contrast to both these cases, a proponent of the cost-benefit approach need show only that courts compare the costs and benefits of particular untaken precautions to determine breach of duty and predicate cause in fact on the ability of the untaken precaution constituting the breach of duty to have prevented the harm that the plaintiff sustained.

\section{B. Cost-Benefit Comparisons and the Case Law}

In a recent article, William Landes and Richard Posner examine a set of cases with the view of defending the $P^{*}$-comparison approach. ${ }^{18}$ These cases can be divided into two groups: cases on negligence reprinted in the Gregory, Kalven, and Epstein torts casebook, ${ }^{49}$ thought by Landes and

general rule of breach of duty.

47. In other words, using the formulation given at supra note 11 , the sole causal issue would be whether the harm sustained arose from a reasonably foreseeable risk.

48. Landes \& Posner, supra note 1, at 892-903.

49. C. GREGORY, H. KALVEN \& R. EPSTEIN, CASES AND MATERIALS ON TORTS 102-30 (3d ed. 1977); see Landes \& Posner, supra note 1, at 899-903. 
Posner to be neutral with respect to their theory; and their own personal selections, which may have been chosen to validate the $\mathrm{P}^{*}$-comparison theory. ${ }^{50}$ For the sake of brevity, the analysis here focuses on Landes and Posner's own selection of injurer negligence cases, ${ }^{\text {b1 }}$ because those cases are the ones that one would expect would support the conventional theory most strongly. But even this latter group of cases provides better support for the hypothesis that courts are using the cost-benefit approach.

It should be noted that Landes and Posner performed this case analysis before they clarified their theory of legal causation. In the article in which the case analysis appears, there is no explicit formal theory of how the cause in fact doctrine limits liability; the formal model relates solely to the breach of duty doctrine, which they model using the $\mathrm{P}^{*}$-comparison approach. ${ }^{52}$ Their more recent clarification of their causation theory explicitly adds the concept of but-for causation to their formal model of the negligence rule. ${ }^{53}$ Hence, Landes and Posner seem now committed to the $\mathrm{P}^{*}$-cutoff rule and not to the full liability rule. In any event, as the following discussion indicates, the cases that they selected to validate their theory clearly do not support the hypothesis that courts are using the full liability rule. ${ }^{54}$ Therefore, the relevant question becomes whether these cases better support the hypothesis that courts are using the $\mathrm{P}^{*}$-cutoff rule or the hypothesis that courts are using the cost-benefit rule.

In Hendricks v. Peabody Coal Co. ${ }^{55}$ the first case from the Landes and Posner selection, the plaintiff, who was a minor, was seriously injured while swimming in the defendant's abandoned strip mine. Consistent with the cost-benefit approach to the breach of duty issue, the court was clear that of the various untaken precautions that the plaintiff had demonstrated, the one constituting the defendant's breach of duty was the defendant's failure to build a "six-foot high steel chain-link fence with steel posts set in concrete surrounding the entire pit." ${ }^{38}$ The court noted that this steel fence would have cost between $\$ 12,000$ and $\$ 14,000$, but concluded that "[t]his cost was slight compared to the risk to the children involved." been taken, would have virtually eliminated the relevant expected harm, so a conclusion that the cost was less than the "risk" was tantamount to a

50. See Landes \& Posner, supra note 1 , at 899.

51. I do not consider Liming v. Illinois Cent. R.R., 81 Iowa 246, 47 N.W. 66 (1890), which is a contributory negligence case, and therefore beyond the scope of this Article.

52. Landes \& Posner, supra note 1 , at 874,882 .

53. Landes \& Posner, Causation, supra note 3, at 115-18.

54. In none of the cases is the analysis consistent with the "causal link" theory of causation. See supra p. 824.

55. 115 Ill. App. 2d 35, 253 N.E.2d 56 (1969); see Landes \& Posner, supra note 1, at 892-93.

56. 115 Ill. App. $2 d$ at 39,253 N.E.2d at 58.

57. Id. at 45,253 N.E. $2 \mathrm{~d}$ at 61 . 
conclusion that the additional cost was less than the reduction in expected harm.

It would be unreasonable to infer from the Hendricks court's opinion a specific finding that the six-foot steel fence set in concrete was necessarily within the set of social-cost-minimizing precautions. The court also laid emphasis on the defendant's failure either to post signs warning of the danger or to police the area effectively. Presumably, some combination of signs and very effective policing would have precluded the plaintiff from showing that the absence of the fence was a breach of duty. What combination of precaution technologies would minimize social cost is something that cases like Hendricks do not decide. All Hendricks decided was that, given the defendant's actual level of precaution, the costs of building a fence would have been less than the reduction in expected harm from doing so and that a fence would have prevented the particular injury that occurred. This limited finding of fact would conclude the liability issue if the court were following the cost-benefit approach; if the court were following the $\mathrm{P}^{*}$-comparison approach, however, the analysis would be far more complicated, since the court would have to determine what combination of these three-and possibly other-precaution technologies would truly minimize social cost.

Adams v. Bullock, ${ }^{88}$ the second case that Landes and Posner discuss, is also one in which the court seems to have been using the cost-benefit approach. Here the court narrowed the possibilities of what untaken precautions might support liability by using cause in fact analysis. The plaintiff was a boy who was shocked when the wire that he was swinging while walking on a bridge came into contact with the defendant's trolley wires. The court noted that "[g]uards [for wires] . . . are of little value." the court meant was that if the defendant had placed the guards "here and there" on the wires, it is doubtful that it would have prevented the particular harm that the plaintiff sustained. ${ }^{60}$ The only untaken precaution that would have satisfied the cause in fact requirement was placing the trolley wires underground. If they had been underground, the plaintiff's harm would have been prevented, because his swinging wire would surely not have come into contact with them. The court was not satisfied "upon the facts exhibited in this record" that the cost of placing the wires under-

58. 227 N.Y. 208, 125 N.E. 93 (1919); see Landes \& Posner, supra note 1, at 893-94.

59. 227 N.Y. at 211,125 N.E. at 94.

60. A similar, but harder, cause in fact issue is presented when the defendant has failed to place fire escapes on a building. Granting this omission to be a breach of duty, courts have denied recovery because of a failure to demonstrate cause in fact. See, e.g., Rosser v. Atlantic Trust \& Sec. Co., 168 Va. 389, 191 S.E. 651 (1937); Berry v. Farmers' Exch., 286 P. 46 (Wash. 1930). To prove cause in fact, the plaintiff has to demonstrate that if a fire escape had been built, it would have been positioned in a way to have allowed the plaintiff (or the plaintiff's deceased) to have escaped. 
ground was justified by the benefits. ${ }^{61}$ There is no suggestion in this case that liability depends on any condition more restrictive than the cost-benefit condition, as would be the case if the court were using the $\mathrm{P}^{*}$-cutoff rule.

In the next case that Landes and Posner discuss, Nussbaum v. Lacopo, ${ }^{62}$ the plaintiff, who had bought a house next to a golf course, was struck by a ball that the defendant had hit. ${ }^{63}$ The court analyzed two untaken precautions, again in the alternative: The defendant's failure to take more care in making his shot to prevent the golf ball from hooking, and the defendant's failure to shout "Fore!" once he knew it had hooked. The court decided that the first untaken precaution did not constitute a breach of duty. The court noted that "[g]olfers are notorious in the tedious preparation they give to a shot." ${ }^{\text {" }}$ So, it was unlikely that the cost to the defendant of further precaution in striking the ball would have been less than the reduction in expected harm, especially when the defendant could see that there was a natural barrier of foliage between the tee and the plaintiff's property. In any event, as the court also noted, "Plaintiff made no effort to show that defendant failed to use due care in striking the ball." precaution in favor of the defendant.

What consumes most of the court's analysis and what the court obviously regarded as the most serious breach of duty issue of the case arose on the second untaken precaution, namely, the defendant's failure to have shouted "Fore!" once he knew that he had hooked the ball. Landes and Posner do not mention this issue in their analysis. Of course, normally the burden of shouting "Fore!" after a seriously hooked shot is less than the reduction in expected harm. The court, however, refused to send the case to the jury, stating: "Living so close to a golf course, plaintiff would necessarily hear numerous warning shouts each day. As the warning would ordinarily be directed to other golfers, plaintiff could be expected to ignore them." ${ }^{38}$ In other words, even if the failure to have taken the precaution of shouting "Fore!" was a breach of duty, it could not have been the cause

61. 227 N.Y. at 211,125 N.E. at 94.

62. 27 N.Y.2d 311,265 N.E.2d 762, 317 N.Y.S.2d 347 (1970); see Landes \& Posner, supra note 1 , at 894-95.

63. Actually there were two defendants, the golfer and the golf course. The untaken precaution alleged against the golf course was its failure to design the course in a way that would reduce the expected harm to those in and around the plaintiff's home. The court resolved this issue with assumption-of-the-risk analysis, saying the evidence was that golf balls only occasionally landed on the plaintiff's property and that "[t]hese invasions are the annoyances which must be accepted by one who seeks to reside in the serenity and semi-isolation of such pastoral setting." 27 N.Y.2d at 317,265 N.E.2d at 765,317 N.Y.S.2d at 353.

64. Id. at 319,265 N.E.2d at 767,317 N.Y.S.2d at 353.

65. Id. at 318,265 N.E.2d at $766-67,317$ N.Y.S.2d at 353.

66. Id. at 318,265 N.E.2d at 766,317 N.Y.S.2d at 353. 
in fact of the plaintiff's harm because this precaution would not have prevented the plaintiff's harm, even if it had been taken. Thus, the court's refusal to send the case to the jury was premised on a "cause in fact" reason, not a "breach of duty" reason..$^{67}$ Because the cost-benefit rule has the same cause in fact requirement as the $\mathrm{P}^{*}$-cutoff rule, this case is no more consistent with the $\mathrm{P}^{*}$-comparison approach than it is with the costbenefit approach, except, of course, that this case does not suggest the existence of the "missing defense" or any other condition of liability more restrictive than the cost-benefit condition.

In these injurer negligence cases that Landes and Posner marshal in support of their $\mathrm{P}^{*}$-comparison theory, the issue that the courts considered was not whether actual precaution was less than the $\mathrm{P}^{*}$-level but whether the cost of at least one specific untaken precaution was less than the benefit. Indeed, at points in their analysis, Landes and Posner write as if they are really trying to validate the cost-benefit approach, not their $\mathrm{P}^{*}$-comparison theory. For example, in their discussion of Blyth v. Proprietors of

67. Landes and Posner make the same error relative to McDowall v. Great W. Ry., [1903] 2 K.B. 331 (C.A.) (Vaughan Williams, L.J.), rev'g [1902] 1 K.B. 618, a Gregory, Kalven and Epstein case, which was also finally decided by the Court of Appeal on cause in fact or proximate cause grounds, not on breach of duty grounds as Landes and Posner write. See Landes \& Posner, supra note 1, at 901-02. In this case, a group of boys broke into one of the defendant's boxcars and sent it rolling down a hill where it crashed into the plaintiff. The defendant's actual level of precaution was high in that the defendant had (1) locked the boxcar, (2) left it braked, and (3) left it coupled to other railcars. The untaken precaution that the plaintiff alleged to be the breach of duty was the defendant's failure to have set the boxcar behind a "catchpoint" as the defendant easily could have done. Because the defendant's actual level of precaution was high, it is doubtful that setting the boxcar behind the catchpoint would have reduced expected harm by any significant amount. The jury found in a special verdict, however, that it was a breach of duty to have failed to set the boxcar behind the catchpoint, and the King's Bench Division entered judgment on the verdict for the plaintiff. The Court of Appeal reversed, and it is this reversal that Landes and Posner are trying to explain. They say that the Court of Appeal found that the evidence of the defendant's breach of duty was insufficient to support the verdict, and that this finding was justified because after all the actual precautions had been taken the marginal reduction in expected harm was "probably negative," suggesting that it would have been inefficient to make even a negligible expenditure to move the car behind the catchpoint. Landes \& Posner, supra note 1, at 907. Landes and Posner's analysis implies that the defendant had taken precaution up to the point where the last units of precaution were actually increasing expected harm. This conclusion seems unlikely. Surely, braking the boxcar, if that was the last unit of precaution, would not have increased expected harm. Rather, the Court of Appeal seems to have decided the case on cause in fact, not breach of duty, grounds. As the court noted in a key passage:

The truth of the matter is that, if it had been placed there [behind the catchpoint], all these

boys would have had to do was to open or close, as the case might be, this catch-point and let

the van go by, which would have been a very much simpler operation than that they went

through when they got into the van, of uncoupling and unbraking the van.

2 K.B. at 336-37. This means that the court found that there was no cause in fact because the untaken precaution said to constitute the breach of duty would not, under the circumstances, have prevented the particular accident that occurred. In a later passage, the court makes this point even more clearly: "II]n my judgment, there is nothing to justify the finding that the not placing the van to the east of the catch-point was an effective cause of the accident which occurred." Id. at 337. The other decisional language in the opinion bears on whether the intervention of the boys should have been reasonably foreseeable to the defendant, which is proximate cause analysis outside the scope of this Article. 


\section{Positive Theory of Negligence}

the Birmingham Waterworks, ${ }^{88}$ Landes and Posner write:

The court was not interested in whether the total costs of burying the main to a depth at which it would not have burst even in the unusually severe frost of 1855 were less than the expected accident costs. It was interested in whether, given that the mains had been buried to a depth that would prevent their freezing in any ordinary frost, the incremental expense of protecting against an unusually severe frost would have been justified by the incremental reduction in accident costs brought about by such an expense. ${ }^{69}$

Evaluating the costs and benefits of a particular untaken precaution seems more consistent with the cost-benefit approach than with the $\mathrm{P}^{*}$-comparison approach. It is true, however, that a court can attempt to locate $\mathrm{P}^{*}$ by searching for untaken precautions that would have been cost-beneficial. Indeed, if an injurer operates at $\mathrm{P}^{*}$, no untaken precaution could possibly have that property. What Landes and Posner neglect, however, is that untaken precautions beyond $\mathrm{P}^{*}$ can have greater benefits than costs when the injurer is taking less precaution than $\mathrm{P}^{*}$. Landes and Posner seem to embrace the cost-benefit condition as the test of liability when they do their case analysis, but they neglect the point that this condition, if it is not further restricted, leads to a liability beyond $\mathrm{P}^{*}$ that is inconsistent with their theory.

\section{Conclusion}

This Article identifies an alternative to the conventional approach of comparing an injurer's level of precaution with the level that would minimize social costs. The proposed alternative, to compare the costs and benefits of an untaken precaution that was a "but for" cause of the accident, is preferable for two reasons. First, as a formal economic model, it appears more likely to promote the minimization of social costs. More importantly, it is more consistent with the actual practice of the courts. Thus, from the standpoint of the two criteria that are relevant to the evaluation of the positive economic theory of tort, the proposed approach performs better than the conventional theory that it seeks to replace.

68. 11 Ex. 781, 156 Eng. Rep. 1047 (1856); see Landes \& Posner, supra note 1, at 895-96.

69. Landes \& Posner, supra note 1, at 896; see also id. at 896-97 (discussing additional costs and benefits of untaken precautions). 


\section{The Yale Law Journal}

Volume 92, Number 5, April 1983

\section{Richard L. Revesz \\ Editor-in-Chief}

Steven G. Calabresi

Note \& Topics Editor

José M. Berrocal

Davison M. Douglas

Cynthia L. Estlund

Carl H. Loewenson, Jr. Note Editors
Robert E. Cooper, Jr. Managing Editor

Martha Grace Duncan George Ellard

Michele S. Hirshman

Eric L. Lewis

H. J. van der Vaart

Article \& Book Review Editors

David E. Brodsky

Sarah Dillian Cohn

Nicholas M. De Feis

Doron A. Henkin

Candice Hoke

Kathryn Abrams

C. Bruce Baker

Stuart E. Bauchner

Thomas H. Bell

Michael T. Brady

Troy Brennan

David A. Broadwin

C. Cabell Chinnis, Jr.

Eric O. Corngold

Peter W. Devereaux

Stephen W. DeVine

Joseph A. Franco

Roger George Frey

Nancy I. Greenberg

David A. Hansell

Robert R. Harding

Joan E. Hartman
Michael A. Jacobs

Valerie A. Lambiase

Janet R. Langford

Gene J. Oshman

\section{Senior Editors}

Dean M. Hashimoto

Eugene G. Illovsky

Samuel Issacharoff

Roberta M. Kania

Pamela S. Karlan

Mercedes A. Laing

Andrew A. Lance

Gary S. Lawson

Peter B. Marrs

Stephen J. Massey

Emily McKillip

Eben Moglen

Meridee Moore

Susan R. Necheles

Daniel R. Ortiz

Linda $\mathrm{M}$. Owens
Robert D. Richman

William H. Rooney

Victoria P. Rostow

Don Sparks

Wendy Warring

\author{
Wes Parsons \\ Patrice M. Pitts \\ Michael B. Rappaport \\ Manley W. Roberts \\ Daniel C. Richman \\ Bennett C. Rushkoff \\ Jeffrey W. Sacks \\ Jefferey M. Sellers \\ John K. Setear \\ Daniel Smirlock \\ Thomas A. Smith \\ Pat Shapiro Spengler \\ Stephanie I. Splane \\ Susan Swift \\ Gene A. Turk, Jr. \\ Stefan R. Underhill \\ Thomas R. Webb
}

\section{Editors}

Business Manager: Pamela Standish Editorial Assistant: Claudia Shapiro

\section{Student Contributors to This Issue}

Joseph A. Franco, Limiting the Anticompetitive Prerogative of Patent

Owners: Predatory Standards in Patent Licensing

Wes Parsons, The Inefficient Common Law 